Agnieszka Wesołowska

Uniwersytet Śląski, Katowice

ORCID: 0000-0002-6611-4129

e-mail: aletheia2@interia.pl

\title{
Etos fenomenologii Husserlowskiej
}

DOI: http://dx.doi.org/10.12775/RF.2019.052

Metafizyka jest dla Husserla poznawaniem bytu jako bytu: imperatywem jednocześnie praktycznym i teoretycznym; rozum teoretyczny jest rozumem praktycznym, podporządkowanym idei pewnego zadania.

Rozważania prezentowane $\mathrm{w}$ niniejszym artykule są skoncentrowane wokół tezy, że w Edmunda Husserla projekcie fenomenologii transcendentalnej namysł nad zadaniami i metodą fenomenologiczną pozostaje w ścisłym związku z aksjologiczno-etyczną motywacją i perspektywą filozofowania niemieckiego myśliciela. Powiązanie to ujawnia się w specyficznym etosie filozofowania Husserla, który można rozumieć jako aksjologiczny. Problemowy i otwarty charakter Husserlowskiego filozofowania, jego aksjologiczny etos i szeroko pojmowana metoda fenomenologiczna, stanowiące o specyfice projektu fenomenologii, mają rozstrzygające znaczenie dla rzetelnej analizy problemów dotyczących człowieka i jego doświadczenia. Fenomenologia jest bowiem pierwotnie motywowana praktyczno-etycznie. Filozofia ta wymaga od filozofującego podmiotu nie tylko określonego sposobu postępowania, lecz przede wszystkim - ze względu na zawarte w niej idee oraz wartości, składające się na "aksjologiczny etos", zadany do realizowania - wprowadza filozofujący podmiot w szczególną atmosferę filozofowania, w duchowy

* Jacques Derrida, „Fenomenologia i domknięcie się metafizyki”, przeł. Małgorzata Kowalska, w: Fenomenologia francuska. Rozpoznanial interpretacjel rozwinięcia, red. Jacek Migasiński i Iwona Lorenc (Warszawa: Wydawnictwo IFiS PAN, 2006), 158. 
wymiar, w którym przebiega proces myślowy. Odwołajmy się w tym kontekście do słów Edyty Stein, która w odniesieniu do momentu osobistego zapoznania się z Husserlowską fenomenologią stwierdza:

Było to dla mnie pierwsze zetknięcie z nieznanym mi dotąd światem. Nie doprowadziło mnie jeszcze do wiary, ale otwarło pewien zakres fenomenu, obok którego nie mogłam przejść jak ślepiec. Nie na darmo wpajano nam stale zasadę, abyśmy do każdej rzeczy podchodzili bez uprzedzeń, odrzucając wszelkie „obawy”. Jedne po drugich, opadały ze mnie więzy racjonalistycznych przesądów, w jakich wzrastałam, nie wiedząc o tym, i nagle stanął przede mną świat wiary ${ }^{1}$.

Fenomenologiczne badanie - jak postaramy się pokazać w niniejszym artykule - jest kwestią nie tyle aktywności teoretycznej, ile przede wszystkim praktyczno-etycznej, kwestią zmiany nastawienia czy perspektywy i tym samym urzeczywistniania oraz respektowania specyficznego etosu. Teza ta zostanie rozpatrzona $w$ ramach prezentowanych rozważań w postaci dwóch kroków: w pierwszej kolejności przedstawimy nastawienie fenomenologiczne jako takie, które umożliwia wgląd $\mathrm{w}$ transcendentalną podmiotowość; następnie etos fenomenologii zostanie ujęty jako dążenie do życia w prawdzie. $W$ artykule koncentrujemy się na filozofii Husserla i przywołujemy komentarze tych fenomenologizujących filozofów, które wydają się istotne dla kwestii fenomenologicznego etosu.

\section{Nastawienie fenomenologiczne jako wgląd w transcendentalną podmiotowość}

Według Husserla żyjący w świecie człowiek jest „,ja” transcendentalnym, ale o tym nie wie, bo w nastawieniu naturalnym transcendentalny charakter człowieczeństwa pozostaje zakryty². „Z całą oczywistością można powiedzieć - pisze Husserl w Medytacjach kartezjańskich... - jako żyjące $\mathrm{w}$ naturalnym nastawieniu Ja, jestem równocześnie i za każdym razem (auch und immer) Ja transcendentalnym, dowiaduję się o tym jednak dopiero, przeprowadzając redukcję fenomenologiczną"3. Z tego punktu widzenia redukcja fenomenologiczna, jako filar metody fenome-

1 Święta Teresa Benedykta od Krzyża, Edyta Stein, Dzieje pewnej rodziny żydowskiej (Kraków: Wydawnictwo Karmelitów Bosych, 2000), 207.

2 Zob. Piotr Łaciak, Anonimowość jako granica poznania w fenomenologii Edmunda Husserla (Katowice: Wydawnictwo Uniwersytetu Sląskiego, 2012), 19-20.

3 Edmund Husserl, Medytacje kartezjańskie z dodaniem uwag krytycznych Romana Ingardena, przeł. Andrzej Wajs (Warszawa: Państwowe Wydawnictwo Naukowe, 1982), 53. 
nologicznej, umożliwia uświadomienie, że jestem zarazem podmiotem świata (,ja” transcendentalnym), jak i przedmiotem w świecie (czyli ,,ja” empirycznym). To podwójne obywatelstwo ,ja" nazywa się paradoksem podmiotowości. Po dokonaniu redukcji zostaje tym samym odsłonięta kwintesencja podmiotowości, jaką stanowi transcendentalność, w którą wgląd nie jest możliwy w nastawieniu naturalnym. Zdaniem autora $\mathrm{Me-}$ dytacji kartezjańskich..., przeprowadzając fenomenologiczną epoché,

redukuję moje stanowiące część przyrody Ja i moje życie psychiczne obszar mojego psychologicznego samodoświadczenia - do mojego Ja transcendentalno-fenomenologicznego, do obszaru transcendentalno-fenomenologicznego samodoświadczenia. Świat, obiektywny świat, który dla mnie istnieje, [...] czerpie [...] cały swój sens i swoją bytową ważność, którą dla mnie w danej chwili posiada, ze mnie samego, ze mnie jako transcendentalnego Ja, wyłaniającego się wraz z transcendentalno-fenomenologiczną redukcją ${ }^{4}$.

Praktyczno-aksjologiczny etos fenomenologii, zadany filozofujące$\mathrm{mu}$,ja" do realizacji, zawiera w sobie wymóg szczególnie rozumianej ascezy poznawczej, która wyraża się w konieczności oczyszczenia badającego podmiotu oraz badanego przedmiotu ze wszelkich zbędnych apercepcji, oczyszczenia stanowiącego istotny rys metody fenomenologicznej. To oczyszczenie umożliwiające zdystansowanie się do samego siebie jest wolnym aktem podmiotu. Odwołajmy się w tym kontekście do Władysława Stróżewskiego, który stwierdza:

moja wolność iść [...] może $\mathrm{w}$ rozmaitych kierunkach: nie tylko w kierunku wyboru i spełnienia określonych działań w sferze tego, co dane mi jest jako "poddające się", a więc możliwe do takiego czy innego podporządkowania się mym działaniom, ale i w kierunku przełamywania tego, co zrazu jest od tej strony niemożliwe, a więc w kierunku przekraczania granicy mego „nie mogę"

Można stwierdzić wręcz, że etos fenomenologii Husserla wiąże się z wolnościa w której ugruntowany jest akt redukcji fenomenologicznej. Specyficznie podmiotowa wolność jest warunkiem fenomenologicznej epoché. W pierwszej księdze Idei czystej fenomenologii... czytamy, że redukcja to kwestia naszej całkowitej swobody.

To przewartościowanie jest sprawa całkowitej naszej swobody i przeciwstawia się wszelkiemu myślowemu zajmowaniu stanowiska, jakie można przyporządkować tezie -

${ }^{4}$ Husserl, Medytacje kartezjańskie, 37.

5 Władysław Stróżewski, Istnienie $i$ sens (Kraków: Wydawnictwo Znak, 1994), 227. 
a jakie się z tym przewartościowaniem nie da pogodzić w jedności pewnego „zarazem” - jako też w ogóle wszelkiemu zajmowaniu stanowiska we właściwym tego słowa znaczeniu'.

Redukcja fenomenologiczna umożliwia przejście od nastawienia naturalnego do nastawienia fenomenologicznego, w którym mamy do czynienia $\mathrm{z}$ badaniem korelacji zachodzącej między świadomością i światem ${ }^{7}$. W związku z problematyką korelacji w Idei fenomenologii Husserl stwierdza:

problem korelacji da się rozwiązać tylko w sferze czystej oczywistości, w sferze danych absolutnych, i dlatego tworzących ostateczne normy, i że zatem w postępowaniu, którego charakterystyczną cechą jest oglądanie, musimy kolejno prześledzić wszelkie podstawowe postaci poznania i wszelkie podstawowe postaci przedmiotów prezentowanych w nim całkowicie albo częściowo, ażeby określić sens tych wszystkich korelacji ${ }^{8}$.

Nieprzypadkowo odwołując się do pojęcia oczywistości, Husserl formułuje zasadę bezpośredniego doświadczenia (zasadę zasad fenomenologii), która głosi, że „wszystko, co się nam w »intuicji «źród łow o (by się tak wyrazić: w swej cielesnej rzeczywistości) przedstawia, należy po prostu przyjąć jako to, jako co się prezentuje, ale także jedynie w tych granicach, w jakich się tu prezentuje $\mathrm{e}^{\prime \prime}$. W ten sposób Husserl twierdzi, że podstawą prawomocnego poznania, podstawą prawomocności twierdzeń jest „źródłowo prezentująca naoczność" (originär gebende Auschauung), którą można określić mianem „oczywistości” ${ }^{10}$. Z kolei w Ideach I czytamy:

${ }^{6}$ Edmund Husserl, Idee czystej fenomenologii i fenomenologicznej filozofii, księga pierwsza, przeł. Danuta Gierulanka (Warszawa: Państwowe Wydawnictwo Naukowe, 1975), 90.

7 Shaun Gallagher, Dan Zahavi, Fenomenologiczny umyst, przeł. Marek Pokrowski (Warszawa: Wydawnictwo Naukowe PWN, 2015), 71.

8 Edmund Husserl, Idea fenomenologii. Pięć wykładów, przeł. Janusz Sidorek (Warszawa: Wydawnictwo Naukowe PWN, 1990), 90.

9 Tamże, 79.

10 Zob. Łaciak, Anonimowość jako granica poznania, 46-54. Oczywistość rozpatrywana $z$ epistemologicznego punktu widzenia stanowi podstawę poznania, którego zakresu nie można z góry określić. Józef Czarkowski pisze o tym następująco: „W tym, że uznajemy oczywistość za ostateczną podstawę poznania, zawiera się przeświadczenie, iż nie możemy z góry wyznaczyć ani zakresu tego, co może być w sposób czysty zobaczone, ani też możliwego zróżnicowania samej oczywistości. Husserl przyjmuje różne modi samoprezentacji, w których manifestują się rozmaite przedmioty i treści". Józef Czarkowski, Filozofia czystej świadomości. Redukcja, refleksja, czysta świadomość w fenomenologii transcendentalnej Edmunda Husserla (Toruń: Wydawnictwo Uniwersytetu Mikołaja Kopernika, 1994), 48. 
Jest całkiem zrozumiałe, że tylko źródłowa oczywistość jest pierwotnym (ursprünglich) źródłem uprawnienia i że np. rozumowe uznanie w bycie zawarte w przypomnieniu i tak samo we wszelkich odtwórczych aktach, wśród nich także we wczuciu, nie jest pierwotne, lecz w pewien sposób pochodne ${ }^{11}$.

Sama redukcja, literalnie rozumiana, polega na zawieszeniu tzw. tezy naturalnego nastawienia, to znaczy przeświadczenia o istnieniu świata przenikającego całe naturalne nastawienie, i jako taka umożliwia zmianę nastawienia z naturalnego na transcendentalne. Jeżeli po dokonaniu redukcji dochodzi jedynie do zmiany nastawienia, skutkującej odsłonięciem korelacji między świadomością i światem, to w nastawieniu fenomenologicznym rzeczywistość nie zmienia się, lecz zmianie podlega tylko jej sens:

nie „zmieniono sensu” realnej rzeczywistości ani nie zaprzeczono jej w ogóle, lecz usunięto niedorzeczną jej interpretację, taką która jest sprzeczna z jej własnym, w naocznie zrozumiały sposób wyjaśnionym sensem. Ta interpretacja pochodzi z filozoficznego zabsolutyzowania świata, które jest całkowicie obce naturalnemu jego traktowaniu. To traktowanie jest właśnie naturalne, żyje naiwnie w spełnianiu opisanej przez nas generalnej tezy, nie może zatem nigdy stać się niedorzeczne ${ }^{12}$.

Obszarem, do którego otwiera dostęp fenomenologiczna redukcja, to znaczy sferą badania fenomenologii, jest zatem świadomość wraz z przedmiotami, do których się ona odnosi, przedmiotami wziętymi dokładnie tak, jak są domniemywane, przy wyłączeniu ich rzeczywistego istnienia. Okazuje się przy tym, jak zauważa Władysław Stróżewski, że

wskutek owego wzięcia w nawias nic $\mathrm{w}$ tym, jak świat jest nam dany, nie ulegnie zmianie. Świat prezentuje się nam dokładnie tak samo, jak poprzednio, jednakże teza stwierdzająca jego istnienie, przedtem jednoznacznie, choć - jak się okaże - naiwnie, żywiona i jednoznacznie przesądzona, zjawi się teraz jako otwarty problem ${ }^{13}$.

Charakterystycznym rysem fenomenologicznej postawy jest szacunek względem rzeczywistości. Kwestię tę dobitnie ujmuje Jacques Derrida, twierdząc, iż

powrócić do rzeczy samych - to uszanować sens wszystkiego, co w ogóle może jawić się świadomości, wszystkiego, co jest dane, i w postaci, w ja-

${ }^{11}$ Husserl, Idee czystej fenomenologii i fenomenologicznej filozofii, 448.

12 Tamże, 182.

13 Władysław Stróżewski, „O metodzie fenomenologii”, w: Jak filozofować?, red. Jerzy Perzanowski (Warszawa: Państwowe Wydawnictwo Naukowe 1989), 81. 
kiej jest dane, w jakiej ukazuje się „we własnej osobie” (leibhaftig) jako to, czym jest w swej źródłowej nagości, odarte z wszelkiego pojęciowego przybrania, które pojawia się jeszcze przed zakryciem owego czegoś przez interpretację spekulatywną ${ }^{14}$.

Świadomość w ujęciu fenomenologicznym jest aktem, w którym dochodzi do ujęcia dotyczącego istnienia tego, co źródłowo dane w samym przeżyciu ${ }^{15}$.

Husserl pokazuje, że zajęcie stanowiska fenomenologicznego umożliwia przyglądanie się światu w taki sposób, w jaki jest on intencjonalnie ujmowany jeszcze $w$ nastawieniu naturalnym. Fenomenologiczne nastawienie ,jest zorientowaniem, które posiadamy, gdy refleksyjnie spoglądamy na naszą postawę naturalną oraz wszystkie zachodzące w niej intencjonalności"16. Odwołajmy się w tym kontekście do Ullricha Mellego, który ujmuje fenomenologię jako „,»Wszechogarniającą filozofię transcendentalnąu i »absolutną naukę o bycie«, »w której wszystko, co przedmiotowe, jest rozwiązywane w swej korelacji «"17. Zdaniem tego komentatora "dotyczy to samo "specyficznych fenomenologicznych przedmiotów «, zjawisk, sądów, mniemań i znaczeń, które zostają objaśnione transcendentalnie poprzez powrót do ostatecznie konstytuującej absolutnej świadomości"18. Źródło obiektywności w fenomenologii stanowi transcendentalna subiektywność, w związku z czym poznawcza korelacja świadomości i świata wiąże się z poznaniem mającym źródło w transcendentalnym samodoświadczeniu. Istotne jest przy tym to, że koncepcja idei konstytucji wiąże się z podkreśleniem aktywnego udziału świadomości w określaniu struktury tego, co poznawane, $\mathrm{z}$ poznaniem zakorzenionym $\mathrm{w}$ transcendentalnym doświadczeniu ego. W Medytacjach kartezjańskich... Husserl pisze o dokonującym się w ego „akcie fenomenologicznego wydobywania na jaw moich własnych zasobów (Selbstauslegung), wydobywania całej realizującej się we mnie konstytucji i wszystkich istniejących dla mnie przedmiotów"119. Okazuje się

14 Jacques Derrida, „Fenomenologia i domknięcie się metafizyki. Wstęp do myśli Husserla", przeł. Małgorzata Kowalska, w: Fenomenologia francuska. Rozpoznania. Interpretacje. Rozwinięcia, red. Jacek Migasiński i Iwona Lorenc (Warszawa: Wydawnictwo IFiS PAN, 2006), 138-139.

15 Por. Andrzej Półtawski, Świat, spostrzeżenie, świadomość. Fenomenologiczna koncepcja świadomości a realizm (Warszawa: Państwowe Wydawnictwo Naukowe, 1973), 48-49.

${ }_{16}$ Husserl, Idee czystej fenomenologii i fenomenologicznej filozofii, księga pierwsza, 54.

17 Zob. Ullrich Melle, „Einleitung”, w: Edmund Husserl, Vorlesungen über Ethik und Wertlehre (1908-1914), hrsg. Ullrich Melle, in: Husserliana - Edmund Husserl, Gesammelte Werke, Bd. 28 (Dordrecht-Boston-London: Cluwer Academic Publishers, 1988), XL.

18 Tamże, XL.

19 Husserl, Medytacje kartezjańskie, 117-118. 
tym samym, że podstawę nadawania sensu wszelkiej faktyczności, a zarazem centrum świadomościowego życia, stanowi samo ego, które - jak pokazuje Husserl - pewność swego istnienia zyskuje dzięki wewnętrznej samoświadomości ${ }^{20}$.

Fenomenologia wymaga od filozofa przyjęcia określonej postawy, umożliwiającej wgląd $\mathrm{w}$ to, co bezpośrednio dane $\mathrm{w}$ doświadczeniu. Zarysowując projekt filozofii fenomenologicznej, określając sposób postępowania, metodę oraz charakterystyczną postawę (nastawienie podmiotu filozofującego), Husserl poszerzył horyzonty możliwego badania, stworzył podstawę umożliwiającą nowe analizy (a tym samym pozwolił na podjęcie wielu fenomenologicznych wątków), znajdujących swój początek $\mathrm{w}$ różnych odmianach doświadczenia. Należy zauważyć, że uznanie źródłowego doświadczenia za punkt wyjścia badania oraz sam opis danych wywiedzionych z tego doświadczenia wymagają szczególnej subtelności $\mathrm{w}$ doborze odpowiednich pojęć i określeń. Zgodnie z fenomenologicznym postulatem Husserla chodzi o to, „,by o człowieku i jego sprawach mówić językiem wyprowadzonym wprost $\mathrm{z}$ doświadczenia człowieka, by rozumieć człowieka poprzez to, co najbardziej ludzkie"21. Wątki filozofii Husserlowskiej odpowiadają problematyce, jakiej powinna sprostać współczesna myśl, szczególnie filozofia, mająca za zadanie obronę samej siebie, obronę myślenia odwołującego się do warunków własnej możliwości, do własnych podstaw. W szczególnym sposobie ujmowania doświadczenia i człowieka, w którym zostaje wyakcentowany aksjologiczny i potencjalny rys egotyczności, można upatrywać aktualności fenomenologii.

\section{Etos fenomenologii jako dążenie do życia w prawdzie}

Jeśli chodzi o szczególny etos filozofowania jako taki, to Józef Tischner stwierdza wprost:

częścią organiczną każdego nurtu filozoficznego są nie tylko explicite sformułowane zasady, tezy, podstawowe pojęcia, metody i rezultaty ich stosowania, lecz także jakiś nieuchwytny, niepozwalający się explicite wyrazić, nastrój filozofii i filozofowania, tak a nie inaczej na gruncie danego nurtu konkretyzowany. [...] Ów na wpół intelektualny, a na wpół emocjonalny nastrój jest wyznaczony nie tyle przez czysto deklaratywną warstwę myśli, ile przez jakieś bliżej nienazwane wartości, którym myśl ta chce służyć lub które chciałaby wyrażać. Każdą filozofię przenika pewien jej tylko właściwy aksjologiczny Ethos. Ujawniają go pośrednio: styl,

20 Zob. Czarkowski, Filozofia czystej świadomości, 104.

${ }^{21}$ Józef Tischner, „,Filozofia i ludzkie sprawy człowieka”, w: Józef Tischner, Świat ludzkiej nadziei. Wybór szkiców filozoficznych 1966-1975 (Kraków: Znak, 1975), 109. 
rytm płynących zdań, dobór słów, stawiane znaki zapytania, momenty przemilczeń, kwalifikacja problemów według ich ważności [...]. Nie jest ten Ethos łatwy do opisania [...]. Wartości, jakie się na niego składają, są wartościami metafizycznymi, estetycznymi, częściowo także szeroko pojętymi wartościami etycznymi, związanymi niczym wspólnym mianownikiem, jakąś wartością szczególną i podstawowa, tą która dla danego nurtu jest najbardziej znamienna ${ }^{22}$.

Fenomenologia jest nie tylko filozofia, lecz specyficznym sposobem oglądania. Podzielając ów pogląd, Max Scheler stwierdza, że w perspektywie fenomenologii powołaniem człowieka, uzdolnionego możliwością duchowego oglądania, jest urzeczywistnianie prawdziwej wartości, jaką jest wartość moralna własnej osoby. Co więcej, postępowanie zgodne $\mathrm{z}$ tym etosem to prawdziwa duma. Istnieje, zdaniem Schelera, tylko jedna duma, mianowicie duma $\mathrm{z}$ własnej wartości moralnej, jako najwyższej wartości ${ }^{23}$. Z postawą fenomenologiczną wiąże się refleksja nad samym sobą. Zmianę nastawienia $\mathrm{z}$ naturalnego na fenomenologiczne można rozumieć jako przebudzenie. Emmanuel Lévinas ujmuje redukcję jako to, co wyrywając człowieka z jego życia w świecie, nie tylko wydobywa podmiot $\mathrm{z}$ jego naiwności, ale również umożliwia obserwowanie własnego ,ja" w trakcie egzystencjalnego życia oraz kształtowanie siebie jako osoby.

Redukcja - pisze Lévinas - jest aktem, dzięki któremu filozof pochyla się nad samym sobą, i, jeśli można tak powiedzieć, „neutralizuje” człowieka żyjącego w świecie, człowieka ustanawiającego ten świat jako istniejący, człowieka zajmującego jakieś miejsce w tym świecie. Redukcja polega na patrzeniu na siebie $\mathrm{w}$ trakcie życia ${ }^{24}$.

Jeżeli chodzi o samą fenomenologię, to przekonanie o aktualności oraz znaczeniu fenomenologicznego etosu $\mathrm{w}$ sposób dobitny wyraża uczennica i asystentka Husserla Edyta Stein:

Trzeba powiedzieć o Husserlu - pisze - że sposób, w jaki kierował on ku samym rzeczom, wychowując, by z całą ostrością zwracać na nie uwagę umysłu oraz opisywać je trzeźwo, wiernie i sumiennie, sposób, w jaki uwalniał od samowoli i pychy w poznaniu, prowadził do skromnej, posłusznej rzeczom i w tym właśnie pokornej postawy poznawczej. Prowadził on również do wyzwolenia się z przesądów, do nieskrępowanej gotowości przyjęcia tego, co naocznie zrozumiałe. I to nastawienie [...]

22 Józef Tischner, „Egzystencja i wartość”, Znak 7/8 (1972): 917.

${ }^{23}$ Zob. Max Scheler, O rehabilitacji cnoty, przeł. Stefan Kołaczkowski (Warszawa: Instytut Literacki, 1937), 8-9.

${ }_{24}$ Emmanuel Levinas, „Teoria intuicji w fenomenologii Husserla”, przeł. Piotr Mrówczynski, w: Fenomenologia francuska, 125. 
wyzwoliło wielu z nas i pozbawiło uprzedzeń wobec katolickiej prawdy $[\ldots]^{25}$.

Urzeczywistnienie idei ugruntowania poznania wiąże się ściśle z namysłem twórcy fenomenologii nad samym procesem filozofowania, nad - jak już zaznaczono - sposobem uwolnienia się od wszelkich schematów, założeń, mniej lub bardziej uświadamianych przesądów czy tradycji. W Kryzysie... czytamy:

Bycie samodzielnym myślicielem, autonomicznym filozofem wypełnia wola uwolnienia się od wszystkich przesądów (Vorurteile), wymaga od niego zrozumienia, że wszystko, co u niego zrozumiałe samo przez się, to przesądy (Vorurteile), że wszystkie przesądy są zsedymentowanymi niejasnościami pochodzącymi z tradycji (a nie jedynie sądy niepewne co do swej prawdy) i że dotyczy to także tego wielkiego zadania, tej idei, która zwie się filozofiąa ${ }^{26}$.

Redukcja fenomenologiczna nie jest dla Husserla epistemologicznym założeniem ani tym bardziej metodologicznym postulatem, lecz z punktu widzenia rozwoju problematyki fenomenologicznej okazuje się nieskończonym zadaniem, ideą mającą wymiar praktyczno-etyczny. Zmiana nastawienia jest aktem angażującym całą osobę, nieustanną praca, dzięki której podmiotowość odsłania się jako pozbawiona wszelkich zafałszowań. Można zaryzykować tezę, że transcendentalny charakter podmiotowości stanowi o godności człowieka, o jego wyrastaniu ponad świat rzeczy. Świadomość jest bowiem transcendentalna $\mathrm{w}$ tym sensie, że nie daje się uprzedmiotowić, to znaczy nie daje się zredukować do świata. Nawiązując do tekstu Karola Wojtyły Podmiotowość $i$ "to, co nieredukowalne" w człowieku, warto uwyraźnić taki sposób ujmowania człowieka, w którym uwzględnia się również to, co w człowieku nieredukowalne i niewidzialne, "co całkowicie wewnętrzne, a przez co każdy człowiek jest jakby naocznym świadkiem siebie samego, swojego człowieczeństwa i swojej osoby"27. Husserlowska próba przezwyciężenia kryzysu nauk i człowieczeństwa to w istocie próba wyzwolenia (oczyszczenia) z największego wśród przesądów, czyli samozasłonięcia swego prawdziwego ",ja", zasłonięcia uniemożliwiającego życie w prawdzie. Fenomenologiczne poszukiwanie transcendentalnego ugruntowa-

${ }^{25}$ Edyta Stein, „Światopoglądowe znaczenie fenomenologii”, przeł. Zbigniew Stawrowski, Logos $i$ Ethos 1 (1992): 77.

${ }^{26}$ Edmund Husserl, Kryzys nauk europejskich i fenomenologia transcendentalna, przeł. Sławomira Walczewska (Toruń: Wydawnictwo Rolewski, 1999), 78.

${ }^{27}$ Karol Wojtyła, „Podmiotowość i to, co nieredukowalne w człowieku”, w: tegoż, Osoba i czyn oraz inne studia antropologiczne, red. Tadeusz Styczeń (Lublin: Towarzystwo Naukowe KUL, 2000), 440-441. 
nia czyni możliwym życie absolutnie odpowiedzialne za samego siebie. Dążenie do transcendentalnego ugruntowania i wyjaśnienie możliwości poznania nieskażonego jakimikolwiek przesądami pozostaje skorelowane z ukazaniem praktyczno-etycznego wymiaru fenomenologii, który zawiera się w zasadzie zasad (zasadzie oczywistości). Fakt ten uwyraźnia Husserl w Erste Philosophie, gdzie akcentuje wartość samoodpowiedzialnego życia jako życia opartego na oczywistości ${ }^{28}$. W Erste Philosophie czytamy bowiem, że etyczne pragnienie życia w prawdzie, w samoodpowiedzialności jest motywującym bodźcem filozofowania: „,̇̇ycie filozoficzne jest życiem z absolutnej samoodpowiedzialności"29. Chodzi o akt woli, umożliwiający zmianę nastawienia z nastawienia naturalnego na nastawienie fenomenologiczne, zmianę warunkującą życie w prawdzie i prawym odnoszeniu się do skutków własnych działań. Filozof realizuje pewien szczególny etos. Mamy przy tym na uwadze odpowiedzialność o wymiarze intersubiektywnym, odpowiedzialność za ogólnoludzką wspólnotę. W rozumieniu Husserla życie oparte na oczywistości jest życiem samoodpowiedzialnym, zadaniem, projektem, którego wartość i możliwość zostają wyjaśnione wraz z dążeniem do transcendentalnego ugruntowania. W fenomenologii możliwość poznania prawdziwego jest kwestią nie tyle aktywności teoretycznej, ile przede wszystkim etycznej, kwestią urzeczywistniania i respektowania etosu. W tym aspekcie Husserl, podobnie jak Sokrates, mając na uwadze wiedzę w sensie episteme, odnosi ją do tego, co jest zawarte w ludzkiej duszy.

Warto zatem zauważyć, że formułując zasadę zasad, dzięki której staje się możliwe przezwyciężenie przesądów, i odwołując się do idei oczywistości, Husserl kładzie kres separacji między teorią a praktyka, poznaniem a życiem, separacji będącej symptomem zbłądzenia nauk i samozapomnienia podmiotowości (pogrążania się jej w anonimowości) ${ }^{30}$. Dążąc do uniknięcia dogmatycznych założeń, wskazuje, że to, co się prezentuje, należy zawsze ujmować w korelacji z doświadczającą (konstytuującą podmiotowością). Odwołując się do Husserlowskiej zasady zasad - chodzi o normatywno-etyczną motywację oparcia myśli i czynów na oczywistości, źródłowym doświadczeniu i naocznym zrozumieniu. Dopiero taka filozofia, filozofia samoodpowiedzialna, zasługuje na miano autentycznej nauki. „Filozofia, autentyczna nauka -

28 Zob. Edmund Husserl, Erste Philosophie (1923/24). Teil 1: Kritische Ideengeschichte, hrsg. von Rudolf Boehm (The Hague: Martinus Nijhoff, 1956), 9.

29 Tegoż, Erste Philosophie (1923/24), Teil 2: Theorie der phänomenologischen Reduktion, hrsg. von Rudolf Boehm, w: Husserliana - Edmund Husserl, Gesammelte Werke, Bd. 8 (Den Haag: Martinus Nijhoff, 1959), 197.

${ }^{30}$ Zob. Łaciak, Anonimowość jako granica poznania w fenomenologii Edmunda Husserla, 28-38. 
czytamy w tekście Fenomenologia $i$ antropologia - dąży do prawd absolutnych, ostatecznych, przekraczających wszelką relatywność" 31 .

Podkreślając znaczenie projektowanej filozofii, Husserl pisze o utracie rozumienia w odniesieniu do sfery naturalnego nastawienia, a nawet o zaślepieniu, które stało się udziałem podmiotowości (ludzkiego rozu$\mathrm{mu}$ ) zarówno w sferze poznania, jak i życia, teorii i praktyki. W Kryzysie nauk europejskich... znajdujemy passus: „najgorszy upadek polega na ślepocie na wielki i autentyczny etos, który stanowi właśnie filozofię, wielką i autentyczną filozofię"32. Zdaniem Husserla

każda wielka filozofia jest nie tylko faktem historycznym, lecz nadto spełnia wielka, ba, jedyną w swym rodzaju funkcję teleologiczną w rozwoju duchowego życia ludzkości, wznosząc mianowicie na najwyższy poziom życiowe doświadczenie, [...] mądrość swego czasu ${ }^{33}$.

Rzetelne i odpowiedzialne uprawianie filozofii nie oznacza przy tym aksjologicznie neutralnej aktywności, lecz stanowi dokonanie par excellence etyczne. W perspektywie takiego ujęcia fenomenologia jawi się jako nauka dążąca do ugruntowania poznania i zarazem odsłaniająca rozstrzygnięcia doniosłe dla życia, jako filozofia uwzględniająca w rzetelnym, racjonalnym i krytycznym namyśle relację między sferą poznania i życia, między sferą teoretyczno-naukową i sferą praktyczno-etyczną. Warto nadmienić, że kwestię relacji między teoretycznym i aksjologicznym (praktycznym) rozumem, między wolnym od wartości (neutralnym) i aksjologicznym bytem podejmuje sam Husserl w cyklu wykładów z 1908/1909 roku. To właśnie w związku z refleksją dotyczącą naukowości, namysłem nad projektem fenomenologii jako nauki oraz krytyką nauk pozytywnych ukazuje on fenomenologię jako naukę o źródle poznania i wykazuje konieczność zajęcia stanowiska transcendentalnego, w którego świetle ujawniają się dokonania transcendentalnej subiektywności.

Istotne jest więc, że Husserlowi od samego początku przyświeca nie tyle cel teoretyczny, ile motywacja etyczna. Swój filozoficzny projekt Husserl rozwija wówczas, gdy w odniesieniu do idei jedności nauki filozofia uległa rozproszeniu oraz podziałowi na różne szkoły i kierunki, tracąc „,jedność duchowej przestrzeni" możliwą do urzeczywistnienia we wspólnym celu, przedmiocie oraz metodzie.

${ }^{31}$ Edmund Husserl, „Fenomenologia i antropologia”, przeł. Sławomira Walczewska, Archiwum Historii Filozofii i Myśli Społecznej 32 (1987): 335.

${ }^{32}$ Tegoż, Die Krisis der europäischen Wissenschaften und die transzendentale Phänomenologie. Eine Einleitung in die phänomenologische Philosophie, hrsg. von Walter Biemel, in: Husserliana - Edmund Husserl, Gesammelte Werke, Bd. 6 (Den Haag: Martinus Nijhoff, 1962), 427.

${ }^{33}$ Husserl, Idea fenomenologii, 62. 
Duchowa nędza naszych czasów - pisze Husserl w Filozofii jako ścisłej nauce - stała się faktycznie nie do zniesienia. [...] Wszelkie życie jest zajmowaniem postaw, wszelkie zajmowanie postaw dokonuje się w zasięgu jakiejś powinności, jakiejś instancji, która wyrokuje o prawomocności lub nieprawomocności, zgodnie z normami pretendującymi do absolutnej mocy obowiązującej. [...] Naturaliści i historyści walczą o światopogląd, a jednak jedni i drudzy z różnych stron pracują nad tym, by idee przeinterpretować na fakty, a wszelką rzeczywistość, wszelkie życie przekształcić w niezrozumiałą mieszaninę faktów, wolną od jakichkolwiek idei. Zabobon faktu wszystkim im jest wspólny ${ }^{34}$.

Zamiast filozofii dążącej do uzasadnienia poznania istnieje filozofia występująca w postaci światopoglądowej, naturalistycznej, irracjonalnej, a nawet historyzmu, która „nie jest jeszcze - pisze Józef Czarkowski w ogóle nauka, wszystko bez wyjątku jest w niej sporne i stanowi sprawę indywidualnych przekonań i punktów widzenia"35. Konsekwencją upadku ideału filozofii jako nauki i rozpadu naukowej jedności staje się z jednej strony niejasność i zachwianie sensu badanego przez nauki przedmiotu, z drugiej strony zafałszowanie norm i przekształcenie życia w irracjonalną mieszaninę faktów. W rozumieniu Husserla tymczasem „od swoich pierwszych początków filozofia pretendowała do tego, aby być ścisłą (strenge) nauka, i to nauka, która czyniłaby zadość najwyższym potrzebom teoretycznym, a pod względem etyczno-religijnym umożliwiałaby życie regulowane przez czysto racjonalne normy"36.

Husserla projekt fenomenologii okazuje się projektem filozofii jako nauki ścisłej i autentycznej, dążącej do sprostania celom zarówno teoretycznym, jak i motywacjom (potrzebom) praktycznym. Warto odwołać się w tym kontekście do Józefa Czarkowskiego, który stwierdza, iż

doniosłość problemu możliwości zbudowania filozofii autentycznej wynika stąd, że problem ten ma wymiar nie tylko teoretyczny, ale i praktyczny. Filozofia jest, zdaniem Husserla, absolutnie niezbędna do wyjaśnienia rzeczywistości i rozumnego ukształtowania życia. Bezład i deformacje w filozofii pociągają za sobą kryzys kultury i całego życia ludzkiego. Nauki szczegółowe nie są w stanie zastąpić filozofii i wyjaśnić nam sensu życia i świata ${ }^{37}$.

${ }^{34}$ Tegoż, Filozofia jako ścisła nauka, przeł. Włodzimierz Galewicz (Warszawa: Wydawnictwo Naukowe PWN, 1992), 73.

35 Czarkowski, Filozofia czystej świadomości, 6.

${ }^{36}$ Husserl, Filozofia jako ścisła nauka, 7.

37 Czarkowski, Filozofia czystej świadomości, 6. 


\section{Zdaniem Husserla}

tylko nauka może ostatecznie przezwyciężyć nędzę, która pochodzi z nauki. [...] Jeżeli pewne specjalne, ale w wielkiej klasie nauk wymagane, nastawienie metodyczne [...] przeradza się w niezdolność do przejścia $\mathrm{w}$ inne nastawienia [...] - to na wszystkie te i tym podobne bolączki istnieje tylko jedno lekarstwo: naukowa krytyka, radykalna [...] nauka filozoficzna, której tu bronimy. Światopoglądy mogą się spierać, tylko nauka może rozstrzygać; a rozstrzygnięcie, którego dokona, zamknięte jest na pieczęć wieczności ${ }^{38}$.

\section{Z kolei w Kryzysie europejskiego człowieczeństwa... czytamy:}

Wprawdzie uniwersalna filozofia wraz ze wszystkimi naukami stanowi tylko cząstkowy przejaw kultury europejskiej, ale sensem wszystkich moich wywodów jest to, że część ta jest, by tak rzec, funkcjonującym mózgiem, od którego normalnego funkcjonowania zależna jest rzetelna, zdrowa duchowość europejska. Bycie człowiekiem na wyższym szczeblu człowieczeństwa albo rozumu wymaga zatem autentycznej filozofii ${ }^{39}$.

Sam kryzys nauk przejawia się w tym, że zostaje zasłonięty podmiotowy charakter człowieka, co skutkuje jego reifikacja, tak że kryzys nauk okazuje się zarazem kryzysem człowieczeństwa. W rozumieniu Husserla nauki nie mają do powiedzenia nic o ludzkim życiu.

Pośród trudów i potrzeb naszego życia - słyszymy - nauka nie ma nam nic do powiedzenia. Wyklucza zasadniczo te właśnie pytania, które dla ludzi, poddanych w naszych nieszczęsnych czasach brzemiennym $\mathrm{w}$ skutki przewrotom, są pytaniami palącymi, pytaniami o sens lub bezsens całego ludzkiego życia. Czy w swej ogólności i konieczności dla wszystkich ludzi nie wymagają one także ogólnego namysłu i odpowiedzi dokonanych na podstawie rozumnego wglądu? Dotyczą one ostatecznie człowieka jako decydującego w sposób wolny o swoim zachowaniu wobec otaczającego go ludzkiego i pozaludzkiego świata, jako wolnego w swych możliwościach rozumnego kształtowania siebie i swego otoczenia. Co o rozumie i nierozumie (Unvernunft), co o nas, ludziach, jako podmiotach tej wolności ma do powiedzenia nauka? Naukowa, obiektywna prawda jest wyłącznie stwierdzeniem tego, czym faktycznie świat jest, zarówno świat fizyczny, jak i duchowy ${ }^{40}$.

Konsekwencją separacji nauki od życia i narastającego rozdźwięku między niezmiennym i zamkniętym w sobie myśleniem a doniosłymi

38 Edmund Husserl, Filozofia jako ścisła nauka..., s. 74.

39 Tegoż, Kryzys europejskiego człowieczeństwa a filozofia, przeł. Janusz Sidorek (Warszawa: Aletheia, 1993), 39.

${ }^{40}$ Tegoż, Kryzys nauk europejskich i fenomenologia transcendentalna, 8. 
zagadnieniami płynącymi z doświadczenia staje się kryzys nauk oraz człowieczeństwa. Matematyczno-przyrodniczy obraz świata doprowadził do ukonstytuowania się nastawienia naturalistycznego, zapoznającego subiektywne źródło świata i nauk o świecie, ich świadomościową genezę. Husserlowski projekt fenomenologii jako nauki wiąże się zatem z namysłem nad poznaniem naukowo-obiektywnym, krytyką obiektywistycznej postaci racjonalizmu, racjonalizmu zapoznającego życie "ja" pozbawione życiowej doniosłości i skażone niedorzeczną absolutyzacją.

Nauki pozytywne realizujące ideę wiedzy obiektywnej i zorientowane jednostronnie zapoznają swą własną podstawę, czyli subiektywność doświadczającą świat i nadającą mu sens, subiektywność będącą skrytym warunkiem wszelkiej nauki. „Pozytywnym naukom - zauważa Piotr Łaciak - brakuje absolutnego uzasadnienia, ponieważ są przeniknięte teoretycznymi naiwnościami, uznawanymi za zrozumiałe same przez się, a w konsekwencji intencjonalność sprawczości transcendentalnej świadomości, w której tworzy się wszelka obiektywność, pozostaje w nich nieuświadomiona"41.

W swym ostatnim dziele Husserl podkreśla zatem, że źródłem kryzysu jest „naiwność nauki obiektywistycznej, która to, co nazywa obiektywnym światem, uważa za uniwersum wszystkich bytów, nie bacząc na to, że sama tworząca naukę subiektywność nie może dojść swych praw w żadnej nauce obiektywnej" ${ }^{42}$. Tym samym - zauważa Dan Zahavi - „nauki pozytywne nie tylko wołają o ontologiczne i epistemologiczne uzasadnienie, ale utraciły one też swoje znaczenie egzystencjalne. To z tego właśnie powodu Husserl zarzuca naukom bankructwo etyczne, jak i filozoficzne" 43 .

Warto odwołać się w tym kontekście do Janssena, który stwierdza, że „kryzys ma [...] funkcję motywującego punktu wyjścia. Daje on konieczny impuls do namysłu nad historią myślenia i zadaniem filozofii współcześnie" ${ }^{44}$. Zdaniem Janssena to właśnie kryzys współczesności ma rozstrzygającą pozytywną funkcję dla odsłonięcia transcendentalno-filozofującego życia. Prezentując rozważania poświęcone problematyce rozwoju nauk, Husserl ukazuje, że ich bujny rozkwit idzie w parze ze zbłądzeniem naukowego sposobu myślenia skutkującym chorobą Europy. Pisze wprost o współodpowiedzialnym za kryzys sposobie my-

41 Łaciak, Anonimowość jako granica poznania, 31.

${ }^{42}$ Husserl, Kryzys europejskiego człowieczeństwa a filozofia, 44.

43 Dan Zahavi, Fenomenologia Husserla, przeł. Marek Święch (Kraków: Wydawnictwo WAM, 2012), 166.

${ }_{44}$ Paul Janssen, Geschichte und Lebenswelt. Ein Beitrag zur Diskussion von Husserls Spätwerk (Den Haag: Martinus Nijhoff, 1970), 203. 
ślenia, które opiera się na fatalnych przesądach i prowadzi do groźnych w skutkach wypaczeń oraz zafałszowań ${ }^{45}$.

Współczesna sytuacja europejskich nauk - pisze w Logice formalnej i logice transcendentalnej - zmusza do radykalnego namysłu. $\mathrm{W}$ gruncie rzeczy utraciły one wielką wiarę $\mathrm{w}$ siebie, $\mathrm{w}$ swe absolutne znaczenie. Nowoczesny człowiek dzisiejszych czasów nie dostrzega [...], że nauka i nowa, formowana przez naukę kultura stanowią samoobiektywizację ludzkiego rozumu czy też uniwersalną funkcję, jaką ludzkość stworzyła, by na gruncie rozumu praktycznego umożliwić sobie prawdziwie zadowalające życie, indywidualne i społeczne. Ta wielka wiara, niegdyś zastępująca wiarę religijna, wiara, że nauka prowadzi do mądrości - do rzeczywiście racjonalnego samopoznania, [a także do] poznania świata i Boga, poprzez, nie zaś do życia, które może uzyskiwać coraz doskonalszy kształt, do życia, które będzie naprawdę warte życia, w "szczęściu”, zadowoleniu, dobrobycie itd. [...] utraciła swa siłę. Żyjemy w świecie, który stał się niezrozumiały i w którym daremnie pytamy o cel, o sens, niegdyś tak wolny od wątpliwości, uznawany zarówno przez intelekt, jak i przez wolę ${ }^{46}$.

Istotnym zamiarem Husserla jest przypomnienie o tym, że dokonania rozumu, którego najwyższa forma manifestuje się w nauce i filozofii, powinny pozostawać doniosłe dla ludzkiego życia.

Psychologowie - pisze w Kryzysie... - wcale nie zauważaja że w tematyce swej nie docierają ani do siebie samych jako twórców tej nauki, ani też do otaczającego ich świata, w którym żyją. [...] Z powodu tego obiektywizmu dusza, która przecież zawsze jest jakimś działającym i doznającym Ja nie może wcale stać się tematem psychologii w przysługującym jej z istoty sensie. [...] Całkiem przeoczono, że obiektywizm jako rzetelne osiaggnięcie badacza kierującego się prawdziwymi normami zakłada właśnie te normy, że nie może on przeto być wywiedziony z faktów, gdyż fakty te są tu już pomyślane jako prawdy, a nie jako urojenia ${ }^{47}$.

Tymczasem to właśnie roszczenie nauk do ostatecznych rozstrzygnięć doprowadziło do kryzysu ${ }^{48}$. W ramach takiego ujęcia jasności nabiera fakt, że to właśnie świadomość kryzysu i związana z nim droga przez krytykę nauk pozytywnych prowadzi do fenomenologii transcendentalnej. W 71. paragrafie pierwszego tomu Badań logicznych, poświęconym kwestii zadań matematyków i zadań filozofów, Husserl pod-

${ }^{45}$ Husserl, Kryzys europejskiego człowieczeństwa a filozofia, 14.

${ }^{46}$ Tegoż, Logika formalna $i$ logika transcendentalna, przeł. Grzegorz Sowinski (Warszawa: Wydawnictwo IFiS PAN, 2011), 4-5.

47 Tegoż, Kryzys europejskiego człowieczeństwa a filozofia, 46.

48 Zob. Łaciak, Anonimowość jako granica poznania, 33. 
kreśla znaczenie badania filozoficznego. Uwyraźniając rolę naukowego instynktu i metody, wyjaśnia:

właśnie dlatego obok zręcznej i metodycznej pracy nauk szczegółowych, ukierunkowanej raczej ku praktycznemu rozwiązaniu i opanowaniu [problemów] niż ku istotowemu wglądowi, potrzebna jest wybiegająca dalej „,krytyczna” i przypadająca w udziale wyłącznie filozofowi refleksja nad poznaniem, zdominowana jedynie przez zainteresowanie teoretyczne i wspomagająca je w jego prawach. [...] Filozofowi nie wystarcza, że potrafimy orientować się w świecie [...]; chce on jasno zrozumieć, czym jest istota "rzeczy”, „procesu”, „przyczyny", „skutku”, „przestrzeni”, "czasu" itp. [...]. Dopiero badanie filozoficzne czyni zrozumiałym naukowe osiągnięcia przyrodnika i matematyka tak, że dopełnione zostaje czyste i rzetelne poznanie teoretyczne. Ars inventiva badacza specjalisty i krytyka poznania filozoficznego to uzupełniające się wzajemnie czynności naukowe, dzięki którym dochodzi dopiero do pełnej (obejmującej wszystkie istotowe odniesienia) jedności teoretycznej ${ }^{49}$.

W odróżnieniu od pozostałych nauk, fenomenologia nie tylko transcendentalnie objaśnia poznanie, ale również uwalnia od samozapomnienia podmiotowość teoretyka, który ten świat bada, opisuje i poznaje. W Logice formalnej i logice transcendentalnej Husserl pisze: „Musimy się wznieść ponad samozapomnienie (Selbstvergessenheit) teoretyka, który w (swym) funkcjonowaniu teoretycznym oddany sprawie, (oddany) teoriom i metodom, nie wie niczego o wewnętrznej (stronie) swego funkcjonowania, który żyje w nich, lecz na samo to funkcjonujące życie nie kieruje tematycznego spojrzenia" ${ }^{\prime 50}$.

Podczas gdy naturalna refleksja nad poznaniem nie opuszcza granic nastawienia naturalnego, fenomenologia transcendentalna interpretuje oraz wyjaśnia wszelkie naukowe i ontologiczne pojęcia w związku $\mathrm{z}$ nadającą sens subiektywnością. Określając zadania fenomenologii, Husserl w Idei fenomenologii podkreśla odmienny od nauk naturalnych punkt wyjścia, metodę oraz pole badań.

Filozofia [...] usytuowana jest $\mathrm{w}$ pewnym - w porównaniu $\mathrm{z}$ wszelkim poznaniem naturalnym - nowym wymiarze, i jakkolwiek wymiar ten, co sugeruje już obrazowy sposób mówienia, dopuszcza istotowe powiązania z wymiarami starymi, odpowiada mu nowa, zasadniczo nowa metoda, która przeciwstawia się metodzie „naturalnej”. Kto tutaj przeczy, ten nie rozumie całej warstwy problemowej swoistej dla krytyki poznania, nie rozumie, dokąd filozofia zmierza, co chce osiągnąć i co nadaje

49 Edmund Husserl, Badania logiczne, t. 1: Prolegomena do czystej logiki, przeł. Janusz Sidorek (Toruń: Comer, 1996), 254-255.

50 Tegoż, Logika formalna i logika transcendentalna, 14. 
jej swoistość i swoiste uprawnienia odróżniające ją od wszelkiego poznania naturalnego i naturalnych nauk ${ }^{51}$.

Z nieustannej problematyzacji kwestii dotyczących człowieka i jego doświadczenia oraz krytycznego namysłu czerpie swą moc Husserlowska fenomenologia. Nieprzypadkowo to właśnie transcendentalna fenomenologia przezwycięża „obiektywizm naturalistyczny i w ogóle każdy obiektywizm w jedyny możliwy sposób, a mianowicie przez to, że filozofującym punktem wyjścia czyni swe Ja, rozpatrywane wyłącznie $\mathrm{w}$ jego funkcji uznawania tego wszystkiego, co ma dlań moc obowiązująca, i poddaje to czysto teoretycznej obserwacji. W tym nastawieniu udało się zbudować absolutnie samodzielną naukę o duchu $\mathrm{w}$ formie konsekwentnego samozrozumienia i zrozumienia świata jako dokonania duchowego" ${ }^{52}$. To właśnie w rezultacie dążenia do przezwyciężenia naturalistycznego obiektywizmu i wypracowania metody uchwytywania istoty ducha powstaje projekt transcendentalnej fenomenologii ${ }^{53}$.

\section{Konkluzja}

Fenomenologia jest przede wszystkim pewną postawą wobec świata i wobec samego siebie jako części świata, postawą będącą efektem przejścia od nastawienia przedrefleksyjnego do nastawienia refleksyjnego, które nakreśla horyzonty wszelkich możliwych zagadnień, zarówno tych, które należą do tradycyjnie rozumianej filozofii teoretycznej, jak i filozofii praktycznej. Nastawienie refleksyjne prowadzi do czystej świadomości jako ostatecznego źródła wszelkiego sensu, który racjonalizuje fakty niedające się zrozumieć w nastawieniu naturalnym, tak że redukcja fenomenologiczna jako zmiana nastawienia $\mathrm{z}$ naturalnego na fenomenologiczne oznacza w efekcie przejście od tego, co irracjonalne, pogrążone $\mathrm{w}$ chaosie ślepych faktów, do tego, co racjonalne, nakierowane na realizację najwyższych wartości. W fenomenologii rozum teoretyczny okazuje się bowiem $\mathrm{w}$ istocie rozumem praktycznym, jako że celem fenomenologii jest nie tylko rozstrzygnięcie problemów teoretycznych, które w szczególności dotyczą warunków możliwości doświadczenia świata, lecz także postawienie „najwyższych i ostatecznych zagadnień", które odnoszą się do sensu historii, sensu kultury, sensu

\footnotetext{
51 Tegoż, Idea fenomenologii, 36-37.

52 Tegoż, Kryzys europejskiego człowieczeństwa a filozofia, 49.

53 Zob. tamże.
} 
ludzkiego istnienia, ludzkiej wolności i nieśmiertelności ${ }^{54}$. W tym kontekście w Medytacjach kartezjańskich czytamy, że

w obrębie sfery faktycznie istniejących monad, a dotyczy to również każdej takiej sfery, którą stanowią monady wzięte jako dające się pomyśleć idealne możliwości istotowe, pojawiają się [także] wszystkie problemy związane z przygodną faktycznościa, problemy śmierci, przeznaczenia, możliwości ",autentycznego" ludzkiego życia (możliwości, od której żąda się, by była, w szczególnym znaczeniu słowa, możliwością jego sensu), a pomiędzy nimi problemy "s e n s u" d z i e jó w, i tak dalej aż po zagadnienia najwyższe. Można powiedzieć także, że są to z a g a d n i enia etyczno-religijne, ale postawione na gruncie, na którym właśnie postawione być musi wszystko, co ma mieć dla nas możliwy $\operatorname{sens}^{55}$.

\section{Bibliografia}

Czarkowski Józef. 1994. Filozofia czystej świadomości. Redukcja, refleksja, czysta świadomość w fenomenologii transcendentalnej Edmunda Husserla. Toruń: Wydawnictwo Uniwersytetu Mikołaja Kopernika.

Derrida Jacques. 2006. „Fenomenologia i domknięcie się metafizyki”, w: Fenomenologia francuska. Rozpoznania/interpretacjelrozwinięcia, przeł. Małgorzata Kowalska, red. Jacek Migasiński i Iwona Lorenc. 138-160. Warszawa: Wydawnictwo IFiS PAN.

Gallagher Shaun, Zahavi Dan. 2015. Fenomenologiczny umyst, przeł. Marek Pokrowski. Warszawa: Wydawnictwo Naukowe PWN.

Husserl Edmund. 1996. Badania logiczne, t. 1: Prolegomena do czystej logiki, przeł. Janusz Sidorek. Toruń: Comer.

Husserl Edmund. 1962. Die Krisis der europäischen Wissenschaften und die transzendentale Phänomenologie. Eine Einleitung in die phänomenologische Philosophie, hrsg. von Walter Biemel. W: Husserliana - Edmund Husserl, Gesammelte Werke, Bd. 6. Den Haag: Martinus Nijhoff.

Husserl Edmund. 1956. Erste Philosophie (1923/24). Teil 1: Kritische Ideengeschichte, hrsg. von Rudolf Boehm. The Hague: Martinus Nijhoff.

Husserl Edmund. 1959. Erste Philosophie (1923/24), Teil 2: Theorie der phänomenologischen Reduktion, hrsg. von Rudolf Boehm. W: Husserliana - Edmund Husserl, Gesammelte Werke, Bd. 8. Den Haag: Martinus Nijhoff.

Husserl Edmund. 1987. „Fenomenologia i antropologia”, przeł. Sławomira Walczewska, Archiwum Historii Filozofii i Myśli Społecznej 32.

54 Zob. tegoż, Medytacje kartezjańskie, 206, 235. Zob. Piotr Łaciak, „Fenomenologia transcendentalna i metafizyka". Archiwum Historii Filozofii i Myśli Społecznej 60 (2015): 263-277.

55 Husserl, Medytacje kartezjańskie, 235. 
Edmund Husserl. 1992. Filozofia jako ścisła nauka, przeł. Włodzimierz Galewicz. Warszawa: Wydawnictwo Naukowe PWN.

Husserl Edmund. 1990. Idea fenomenologii. Pięć wykładów, przeł. Janusz Sidorek. Warszawa: Wydawnictwo Naukowe PWN.

Husserl Edmund. 1975. Idee czystej fenomenologii i fenomenologicznej filozofii, księga pierwsza, przeł. Danuta Gierulanka. Warszawa: Państwowe Wydawnictwo Naukowe.

Husserl Edmund. 1993. Kryzys europejskiego człowieczeństwa a filozofia, przeł. Janusz Sidorek. Warszawa: Aletheia.

Husserl Edmund. 1999. Kryzys nauk europejskich i fenomenologia transcendentalna, przeł. Sławomira Walczewska. Toruń: Wydawnictwo Rolewski.

Husserl Edmund. 2011. Logika formalna i logika transcendentalna, przeł. Grzegorz Sowiński. Warszawa: Wydawnictwo IFiS PAN.

Husserl Edmund. 1982. Medytacje kartezjańskie z dodaniem uwag krytycznych Romana Ingardena, przeł. Andrzej Wajs. Warszawa: Państwowe Wydawnictwo Naukowe.

Janssen Paul. 1970. Geschichte und Lebenswelt. Ein Beitrag zur Diskussion von Husserls Spätwerk. Den Haag: Martinus Nijhoff.

Levinas Emmanuel. 2006. Teoria intuicji w fenomenologii Husserla, przeł. Piotr Mrówczynski. W: Fenomenologia francuska. Rozpoznania/interpretacje/rozwinięcia, przeł. Małgorzata Kowalska, red. Jacek Migasiński i Iwona Lorenc. 91-125. Warszawa: Wydawnictwo IFiS PAN.

Łaciak Piotr. 2012. Anonimowość jako granica poznania w fenomenologii Edmunda Husserla. Katowice: Wydawnictwo Uniwersytetu Śląskiego.

Łaciak Piotr. 2015. „Fenomenologia transcendentalna i metafizyka”. Archiwum Historii Filozofii i Myśli Społecznej 60: 263-277.

Melle Ullrich. 1988. „Einleitung”, in: Edmund Husserl, Vorlesungen über Ethik und Wertlehre (1908-1914), hrsg. Ullrich Melle, in: Husserliana - Edmund Husserl, Gesammelte Werke, Bd. 28. Dordrecht-Boston-London: Cluwer Academic Publishers.

Półtawski Andrzej. 1973. Świat, spostrzeżenie, świadomość. Fenomenologiczna koncepcja świadomości a realizm. Warszawa: Państwowe Wydawnictwo Naukowe.

Scheler Max. 1937. O rehabilitacji cnoty, przeł. Stefan Kołaczkowski. Warszawa: Instytut Literacki.

Wojtyła Karol. 2000. „Podmiotowość i to, co nieredukowalne w człowieku”. W: Karol Wojtyła, Osoba i czyn oraz inne studia antropologiczne, red. Tadeusz Styczeń. 433-444. Lublin: Towarzystwo Naukowe KUL.

Stein Edyta. 1992. „Światopoglądowe znaczenie fenomenologii”, przeł. Zbigniew Stawrowski. Logos i Ethos 1.

Stróżewski Władysław. 1994. Istnienie i sens. Kraków: Wydawnictwo Znak.

Stróżewski Władysław. 1989. „O metodzie fenomenologii”. W: Jak filozofować?, red. Jerzy Perzanowski. 78-96.

Święta Teresa Benedykta od Krzyża, Edyta Stein. 2000. Dzieje pewnej rodziny żydowskiej. Kraków: Wydawnictwo Karmelitów Bosych. Warszawa: Państwowe Wydawnictwo Naukowe. 
Tischner Józef. 1972. „Egzystencja i wartość”. Znak 7/8: 917.

Tischner Józef. 1975. „Filozofia i ludzkie sprawy człowieka”. W: Józef Tischner, Świat ludzkiej nadziei. Wybór szkiców filozoficznych 1966-1975. 109-125. Kraków: Znak.

Zahavi Dan. 2012. Fenomenologia Husserla, przeł. Marek Święch. Kraków: Wydawnictwo WAM.

\section{Streszczenie}

Główna teza artykułu brzmi, iż Husserla projekt transcendentalnej fenomenologii pozostaje w ścisłym związku z aksjologiczną i etyczną motywacją filozofowania niemieckiego filozofa. Ten związek rozpatrywany jest $\mathrm{w}$ odniesieniu do specyficznego etosu Husserlowskiej filozofii, który można opisać jako aksjologiczny. To właśnie etyczna i praktyczna motywacja decyduje o specyfice fenomenologicznej drogi filozofowania oraz zmiany nastawienia, którą Husserl określa mianem fenomenologicznej redukcji. $\mathrm{W}$ artykule ta kwestia jest rozpatrywana $\mathrm{w}$ ramach dwóch kroków: $\mathrm{w}$ ramach kroku pierwszego przedstawimy fenomenologiczne nastawienie jako takie, które umożliwia wgląd w transcendentalną subiektywność. W ramach drugiego kroku rozpatrzymy etos fenomenologii jako asumpt do życia $\mathrm{w}$ prawdzie. W ujęciu Husserla praktyczny etos fenomenologii jest wyrazem potrzeby oczyszczenia podmiotu $z$ wszelkich bezużytecznych przesądów.

Słowa kluczowe: fenomenologia, etos, Edmund Husserl, subiektywność, filozofia

\section{Summary}

\section{The Ethos of Husserl's Phenomenology}

The main thesis of this article is that Husserl's project of transcendental phenomenology remains in a close connection with axiological and ethical motivation of the German thinker philosophizing. This relation is reflected in a specific ethos of Husserl's philosophy which can be described as axiological. It is the ethical and practical motivation which affects the specificity of the phenomenological way of philosophizing and the change in the attitude that Husserl described as the phenomenological reduction. In the article, this question is considered in two steps. Within the framework of the first step, we present phenomenological attitude as such which enables insight into transcendental subjectivity. Within the framework of the second step, ethos of phenomenology will be captivated as aspiration for living in truth. According to Husserl, the practical ethos of phenomenology is expressed as a need to purify the subject of useless prejudices.

Keywords: phenomenology, ethos, Edmund Husserl, subjectivity, philosophy 